\title{
INNOVATIVE APPROACHES TO THE REGIONAL DEVELOPMENT IN UKRAINE
}

\author{
Volodymyr ANDRYSHYN', Oleksandr BUTUSOV² \\ Uzhhorod National University, Ukraine
}

\begin{abstract}
The purpose of the paper is the detection, theoretical study and the analysis of key innovative approaches to regional development in modern conditions and the justification of a necessity of their use in practice. Methodology. The study is based on theoretical methods to study this problem. Theoretical and methodological basis of the study are works of scientists on the innovative approaches to the regional development in modern conditions. The dialectical method of cognition, as well as such methods as a systematic and structural analysis, logical generalization are used to study the formation of scientific positions and forming the methodological foundations of the innovative approaches to regional development. Results of the survey showed that among the existing innovative approaches to the regional development two are considered to be the most suitable in the present conditions - interregional cooperation and cluster approach. Theoretical, methodological and practical aspects of regional development, which determine the transformation of the socio-economic relations in the context of sustainability of regional development and are caused by using innovative approaches to the regional development, are described. Practical implications. The priorities of the dynamic regional development through activization of interregional economic cooperation and development of regional and interregional clusters are defined. The development of interregional and international cooperation, implementation of the potential of regional cluster initiatives, development of the system of innovation-oriented investment projects, innovative development of the industry and the realization of its export potential can lead to the qualitative structural shifts in the socio-economic development of regions and Ukraine as a whole. Value/originality. Despite the existing considerable experience of the implementation of these processes in highly developed countries, the assumption is made that the most suitable alternative for Ukraine's economy is not mechanical copying of foreign experience but taking into account only the main features. Considerable interest shows the experience and peculiarities of using innovative approaches to the regional development especially in countries with economies in transition and in developing countries.
\end{abstract}

Key words: region, regional development, innovative approach, interregional cooperation, cluster approach.

JEL Classification: P25, O17, R11

\section{Introduction}

In the context of globalization the regions of Ukraine meet new challenges concerning intensive development of new approaches and techniques of managing, challenges in the practical use of innovative mechanisms and instruments to stimulate socio-economic development of territories, which are successfully used in the world.

Studying of approaches to regional development in Ukraine is of particular relevance, because of the proven relationship between the level of socio-economic development of the countryandits regions' development. The issues of reproduction of the productive forces are solved at the level of regions, projects for socio-

\footnotetext{
Corresponding author:

${ }^{1}$ Department of Enterprise Economics, Uzhhorod National University. E-mail: volodymyr.andryshyn@uzhnu.edu.ua

${ }^{2}$ Department of Enterprise Economics, Uzhhorod National University.

E-mail: alex.butusov1@gmail.com
}

economic development are implemented, key social needs of the population are satisfied and indicators of regional economic development is a criterion for determining the level of economic development of the state as a whole. Nowadays new and modern forms of organization of management of regional production systems that contribute to the development of the regions should be created. This can be done through the introduction of new and improvement of current approaches to regional management and justification of theoretical and methodological aspects of management of development of the regions of Ukraine, as well as identifying features of their development become extremely important scientific and practical tasks. 
In economic literature there are different approaches and opinions regarding the improvement of the mechanisms of socio-economic development of the region. In particular, these issues are the subject of works of scientists: S. Bila, N. Gavkalova, L. Hryshyna, V. Havrylenko, L. Horal, T. Voytkiv, S. Sokolenko, M. Khmara and others.

\section{Definition of the essence of regional development}

First of all, it should be mentioned that the region is a certain part of the country and is characterized by unity, uniformity, and complexity. There is no single clear definition of "region". Different authors have different interpretations of its content, based on the analogy of this definition with the concept of "economic region" or giving it a slightly different content. The term "region" appeared later, than the term "district", but they are often used synonymously. The regions in the understanding of the concept of state regional policy and the Law of Ukraine "On Stimulation of Regional Development" are the territorial units with a system of bodies of executive power and bodies of local self-government (the Autonomous Republic of Crimea, regions, cities of Kyiv and Sevastopol).

Regions serve as the basis for sustainable socioeconomic development of the country due to the fact that the initial accumulation and distribution of human, intellectual and social capitals, natural, logistical, financial and other resources take place at the region level. That is why the regional development has strategic importance and is one of the most important things for the country development (Gavkalova, 2013).

If we consider the region as a complex economic system, we meet the problem of planning and management of its socio-economic development. The modern economics pays more and more attention to the study of problems of development, because this concept is considered to generate changes and achieve a new quality level of the current operation. The development is associated with changes that can significantly differentiate an object from a previous state and this difference means the acquirement of a new quality.

The development is defined as a closely related process of quantitative and qualitative transformations. Quantitative changes - growth, means an increase or decrease of the constituent parts of the organization. Qualitative changes are the transformation of the structure and functions of the organization, its parts and elements. The last ones are not to be accompanied with a change of quantitative characteristics (Dakus \& Simchenko, 2012).

The development as a category can be considered from a several points of view, namely: the development as the process (movement), as a result, as an attribute, as a regularity, as a dynamics (Kuzmin \& Melnik, 2011).
Optimization of any process should lead to the improvement of the state of the object and its results, what is the purpose of development.

\section{Description of innovative approaches to the regional development}

Hryshyna and Havrylenko (2014), exploring innovative approaches to the development of the region note that an important part of innovative tools for the development of the region in conditions of integration processes is the formation of regional and interregional clusters in Ukraine that will contribute to the development of technology-intensive enterprises and the benefits of company's specialization. The cluster organization of production is observed now in traditional industries: construction, light industry, agriculture, while the priority for the European countries is the development of primarily high-tech innovation clusters in the fields of engineering and biotechnology. At the same time, Hryshyna and Havrylenko argue that in the context of integration processes the interregional cooperation is one of the most effective mechanisms of activation of innovative processes and investment for the realization of highly efficient innovative projects. Improvement of existing and development of new interregional economic relations and cross-border cooperation will increase the role of regions in foreign economic cooperation, their active participation in the activities of international organizations. This is possible to achieve it if new full-fledged projects and programs aimed at sharing the resource potential of the regions and achievement on this basis of stable, sustainable development will be prepared and implemented at the interregional level.

A similar assumption is expressed by Pinko (2016), stating in her study that a strong innovative potential for enhancing regional development has the creation of regional and interregional clusters, stimulating productivity, investment in technologically innovativeoriented production, transport, transit, recreation and tourism regional complexes. Regional and interregional clusters form a solid basis for solving problems of employment and import substitution, accelerate the growth of the competitive potential of the territories, ensure social stability. Another important approach, enhancing regional development, states the scientist, is the use of the potential and benefits of interregional cooperation, which contributes to the development of the internal market, strengthen economic and social cohesion of the country. The innovative component of the interregional cooperation is focused on sustainable and balanced socio-economic development at the national level by improving the competitiveness of regions. Due to the implementation of common interregional projects in the field of production, services, infrastructure the socio-economic situation in 
the regions is improved and the economic cooperation between depressed regions and regions-leaders is enhanced; disproportions of regional development are levelling; opportunities are created to learn new and not involved previously resources for development. The international interregional cooperation on the cross-border, transnational level and interregional cooperation opens up new opportunities for Ukraine with the neighbour countries.

Chukhno (2015) examines approaches to the region development from the point of view of management and distinguishes two areas: approaches using methods and tools of regional commercial management (for example, the use of project management approaches, more attention to the effectiveness of interventions, including economic, effective system of motivation of personnel (using the economic methods of motivation), increasing of client focusing etc.); approaches that involve public organizations, communities, local businesses to the processes of regional development management (public involvement in the creation and implementation of regional development programs, public-private partnership, etc.). Among the existing innovative approaches to regional development Chukhno points out the following:

- clusters - the creation of conditions for the emergence and development of clusters in various spheres of life of the region will contribute to the unification of scientific and industrial potential of regions, when applied correctly, can contribute to the solution of strategic tasks of regional development, improvement of socio-economic indicators and the development of industrial and social infrastructure of the region. However, the previous experience of creation of clusters on the basis of the initiative of government agencies and administrative enforcement proved ineffective, the role of the state in this matter should be to develop ideas, creating a support mode for cluster members, etc.;

- public-private partnerships - the main objective of the partnership, based on the experience of foreign countries, is the development of social infrastructure and meeting social and household needs of the population. Public-private partnerships are created and operate in our country, however, such partnerships are not widespread and their activity is not sufficiently effective due to the imperfection of the legislation in this matter, the weak protection of the interests of the private partner, instability of the legislative base and influence of the political situation on these partnerships;

- interregional cooperation in modern conditions

- this approach to the management of regional development is of particular relevance and can bring significant benefits as to individual regions and to the state as a whole. The creation of different types of interregional cooperation in the economic, social, cultural, educational and other areas, in addition to raising the development potential of regions and the achievement of direct economic or social outcomes from such interactions will contribute to establishing interregional relations, which deteriorated as a result of social processes taking place in our country recently and speculation of a significant part of political forces at the regional differences. Interregional cooperation with other countries will strengthen the capacity and pace of development of border regions, as well as further integration of Ukraine into the European community.

Proponents of the cluster approach in regional development Horal, and Voytkiv (2012) believe that cluster development of regions is one of the characteristic features of the modern innovative economy. Clustering can become one of directions of development of the economy and maintain it at the proper level in the system of world economic relations for the regions of Ukraine, say the researchers. Economy-driven cluster is a model of a competitive and investment-attractive economy, providing high level and quality of life of the population. However, it should be mentioned that the cluster will bring the expected results only when their activities are adapted to the dynamic changes in the external environment that surrounds them. Basing on studying the world experience of formation and functioning of clusters, the researchers came to the conclusion that a new promising form of interaction between authorities, businesses and the public can become their joint membership in territorially-sectorial clusters as voluntary associations of complementary territorial resources. In the last decade, clusters and regional policies based on them are the most successful tool of economic development of regions in Western countries. Scientists came to the conclusion that cluster initiatives that support forms of cooperation between enterprises, public sector institutes (universities, research centres), are the driving forces of economic growth and employment growth in many regions of the world.

Zaharchenko and Zaharchenko (2009), basing on studying of foreign practice of clustering of the economy in the regions also inclined to the feasibility and relevance of creating cluster structures in Ukraine. Moreover, the researchers believe that the competitiveness of Ukraine in general and at the regional level in particular will largely depend on how quickly will shape and unfold the support model and the development of modern cluster structures. However, the scientists are against the mechanical copying of foreign experience clustering of the economy while creating clusters in Ukraine. From the position of the transformation of the economy using the cluster approach to the regional development should provide, according to the scientists, enhancing its competitiveness through:

- conversion of companies and organization of new production companies and corporate structures, regional-based (production and trading, manufacturing and financial); 
- increasing of profitability and competitiveness of production, both individual companies and their alliances;

- diffusion of innovation: within corporate structures, and in the innovation space around so called "growth poles".

- market self-management at the regional level, which already manifests itself in the formation of regional systems of market relations, regional markets and market infrastructure.

In the context of a clustering of Ukraine's economy a considerable interest shows the experience of creation, developing and functioning of clusters, especially in countries with economies in transition and in developing countries. The original synthesis of this experience was made by Sokolenko (2006). Based on the analysis of international practices of implementation of cluster strategies, the scientist makes the following policy conclusions:

- application of the cluster approach is a natural stage in the development of the modern economy and is the key to the development of a highly developed economic system;

- advantage of the cluster production mechanism is that it is based on the effective combination of internal cooperation in the process of production with the internal competition within the industrial cluster. It uses the network character of interaction of its participants, because the horizontal integration facilitates the formation of a focused chain of distribution of new knowledge, technologies and innovations. The specificity of the cluster is getting its members a synergistic effect that is reflected in the competitiveness of the whole system compared to individual economic entities;

- distinctive feature of the cluster is its innovative orientation. The most successful clusters' forms are those where there is ongoing or anticipated "breakthrough" in the field of technology and production technology, followed by access to new market niches. That is why all countries are actively using the cluster approach in the formation and regulation of their national innovation programs;

- realization of a cluster policy is based on the organization of interaction between bodies of state power and local self-government, business and educational institutions. Their coordination promotes innovative production and services, mutual improvement and strengthening the effectiveness of their work;

- competitive clusters tend to have developed relationships with similar clusters in other regions and countries. The promotion of such international linkages is becoming an important part of cluster policy, accelerates the development of cooperation between related clusters, and increases the efficiency of their cooperation.

Khmara (2013), exploring the use and application of the cluster approach to the development of the region explains its innovative character - clusters have a greater ability to innovate because of the following reasons:

- participants of the cluster are able to more adequately and quickly respond to the requirements of buyers;

- members of the cluster facilitates access to new technologies, which are used in various fields of business;

- suppliers and consumers even from other industries enter the process of innovation;

- cost of $R \& D$ is reduced as a result of cooperation between the companies;

- firms are under the intensive competitive pressure in the frameworks of cluster.

The scientist points out the differences between traditional industrial clusters and the innovation ones. The reason is the existence of a system of close relationships between firms, their suppliers and customers and knowledge institutions, among them research centres and universities who are generators of new knowledge and innovations, provide high educational level of the region. You have the option of coordinating efforts and resources to create new product and technologies. In essence, the cluster makes possible the existence of a closed process chain, from product creation to production and to market entry. Another discrepancy of innovative clusters from traditional ones, says Khmara, is creating within them mainly exportoriented products and technologies that means that inner competitive advantages are more significant on an international scale (Khmara, 2013).

The most comprehensive in the sense of identification and substantiation of modern approaches to the development of the region is the survey of the team of scientists led by Bila (2011).

The use of innovative approaches to regional development, according to Bila, should be focused on the following:

- strengthening of inner motivation at the regional (local) level of socio-economic growth;

- creation at the regional level of effective economic structures, focused on the intensification of the resource potential use;

- creation at the regional (interregional) level of competitive manufacturing systems of innovative type;

- satisfaction of internal needs of the territories by using own and attracted resources.

Interregional cooperation within a country can substantially expand the total effective capacity of the domestic market, it not only contributes to the realization of material interests of regions, but it is a way of fostering the social, humanitarian, social and cultural relations of the communities (Bila, 2011). Interregional cooperation, according to Bila, is a tool to solve internal problems, not on the basis of competition for the attraction of the centralized financial resources, obtain budget subsidies and subventions or regional tax preferences, but on the basis of more efficient use of 
resources development of the region. This reduces the burden on the state budget for solving problems of the local (regional) development. Interregional cooperation is one of the most effective mechanisms for enhancing innovation processes and to attract investments for the realization of highly efficient innovative projects, is able to form new centres of economic development, around which areas of economic growth can be formed because of the possibility of consolidating resources and efforts of the regions in the implementation of projects of common interest.

Interregional cooperation should be considered as a powerful organizational innovation that significantly improves the efficiency of regional policy through:

- development of subjectivity of regions, increasing their ability to produce their own initiatives and development projects to create the appropriate infrastructure development. Under these conditions, the role of the state lies not in generating, but in the direction of development, which requires a much lower financial and managerial resources;

- features of formation of national projects of macroregional (interregional) level, allowing to achieve the proper importance of the national projects and, accordingly, the multiplier effect brought by the project funds;

- ability of integrated development of territories (including depressed regions), due to the greater detailing of the process of cooperation that becomes possible due to the development of areas of cooperation at the local level;

- providing practical dimension of the European integration strategy of Ukraine by establishing direct communication between the interested partners in interregional cooperation with the EU regions;

- direction of state support of regional development at consolidated design problem that allows to avoid the dispersion of resources and minimization of misuse of funds, to achieve a cumulative effect as a result of this support.

Regarding the cluster approach to regional development, researchers note that the main advantages of cluster organization of production are:

- strengthening cooperation between business, science and government. World practice shows that the establishment of clusters often occurs in the framework of public-private partnership with active participation of the state as a founder and sponsor of cluster initiatives;

- stages as well as research institutes that play a bridging role between industry, government and science;

- increase of efficiency of work thanks to fast access to resources, knowledge, innovative technologies and vendors, as well as by reducing transaction costs;

- intensification of innovation activities of companies. Thanks to the so-called spillover effect and closer contact with consumers and other companies, the ability exists to create and disseminate new ideas and technologies among cluster members and borders, which promotes primarily the growth of value added products and the orientation on production and manufacturing high-tech products of final consumption;

- improving the investment attractiveness of the regions and the country as a whole, due to the high level of investor confidence in the developed network structures (compared to individual small companies), and the presence of guarantees and benefits to investors and to the state if its participation in cluster initiatives;

- accelerating the creation and development of new business. New companies have the opportunity to develop in favourable conditions through the coordination of partner relationships within the cluster; - formation of a closed production cycle (and chain growth of value added) within the country by creating within the cluster missing earlier production units that are directly connected with the development of import substitution (Bila, 2011).

\section{Conclusions}

According to the above mentioned scientists conclusions, innovative approaches to the regional development should be implemented primarily in the following areas: the use of catalysts and multipliers of regional development; motivation of regions to selfdevelopment, diversification of areas of economic activity, search and leveraging the latent potential of the development; overcoming of the paternalistic expectations, minimization of subsidized and fund support mechanisms for the regions.

The need to ensure the development of the regions based on innovation is caused by the importance of the optimization of the spatial economic characteristics of Ukraine in accordance with the peculiarities of allocation of available and potential resources, also by the requirement to meet the general and specific needs of the population.

At the same time, the use of innovative approaches to the regional development should be focused on: strengthening the internal motivation at the local level socio-economic growth; creation at the regional level of effective management structures aimed at intensification of use of the resource potential; formation of interregional and regional levels competitive production innovative systems; satisfaction of internal needs of the territories at the expense of own and attracted resources.

Prospects of further studies on this issue are to determine the characteristics of some innovative approaches in the management of regional development from the point of view of the specific circumstances and ensuring integrated development of Ukrainian regions. 


\section{References}

Bila S.O. (2011). Innovative approaches to regional development in Ukraine: analytical report: the monogram. Kyiv: NISI, 80 p.

Chukhno I. (2015). Innovative approaches in the management of regional development. Theory and practice of public administration 1(48): 165-170.

Dakus A.V. \& Simchenko N.O. (2012). The economic development of enterprise: concept and definition. Actual problems of Economics and management, 6. Retrieved from: : http://probl-economy.kpi.ua/pdf/2012-3.pdf

Gavkalova N.L. (2013). Management of regional development: problems and prospects: the monogram. - Kharkiv: KhNUE, $400 \mathrm{p}$.

Horal' L. \& Voytkiv T. (2012). The usage of cluster approach as the condition for efficiency of innovation development of the region. Economic analysis, 10(1): 112-115.

Hryshyna L. \& Havrylenko V. (2014). Innovative development approaches of the region under the integration processes. Economy and management of enterprises, 1: 126-131.

Khmara M. (2013) Cluster approach of strategy innovation development for foreign countries. International relations, 1(40): 51-54.

Kuzmin O.E. \& Melnik O.G. (2011). Diagnostics of potential of enterprise. Marketing and management of innovations. The scientific journal: 155-164.

Pinko V. S. (2016) Innovative ways of economic development and their implementation at the regional level. Retrieved from: http://www.economy-confer.com.ua/full-article/1971/

Sokolenko S. (2006). Strategy of competitiveness of Ukraine's economy based on the integration of systems clusters. Sevastopol. Retrieved from: http://www.zoa.gov.ua/source/partition/1/00000039800001.doc

Zaharchenko V. \& Zaharchenko S. (2009). Cluster approach to the analysis and improvement of competitiveness of economy of Ukraine and its regions. Bulletin of Khmelnitsky national University, 5: 55-57.

\section{Владимир АНДРИШИН, Александр БУТУСОВ}

\section{ИННОВАЦИОННЫЕ ПОДХОДЫ К РАЗВИТИЮ РЕГИОНОВ В УКРАИНЕ}

Аннотация. Целью работы является выявление, теоретическое обоснование и анализ основных инновационныхподходов к региональному развитиюв современныхусловияхи обоснованиенеобходимости их использования на практике. Методика. Исследование базируется на теоретических методах для исследования этой проблемы. Теоретической и методологической основой исследования являются труды ученых о внедрении инновационных подходов к региональному развитию в современных условиях. Диалектический метод познания, а также следующие методы:системного и структурного анализа, логического обобщения используются для изучения формирования научных позиций и формирования методологических основ инновационных подходов к региональному развитию. Результаты исследования показали, что среди существующих инновационных подходов к региональному развитию два считаются наиболее подходящими в нынешних условиях - межрегиональное сотрудничество и кластерный подход. Описаны теоретические, методологические и практические аспекты регионального развития, которые определяют трансформации социально-экономических отношений в контексте устойчивого регионального развития и обусловлены использованием инновационных подходов к региональному развитию. Практическое значение. Определены приоритеты динамичного развития регионов за счет активизации межрегионального экономического сотрудничества и развития региональных и межрегиональных кластеров. Развитие межрегионального и международного сотрудничества, реализация потенциала региональных кластерных инициатив, развитие системы инновационно-ориентированных инвестиционных проектов, инновационного развития промышленности и реализации ее экспортного потенциала может привести к качественным структурным сдвигам в социально-экономическом развитии регионов и Украины в целом. Значение/оригинальность. Несмотря на существующий значительный опыт реализации этих процессов в высокоразвитых странах сделано предположение, что наиболее подходящий вариант для экономики Украины это не механическое копирование зарубежного опыта, а учет только ключевых составляющих. Немалый интерес показывает опыт и особенности использования инновационных подходов к региональному развитию, особенно в странах с переходной экономикой и в развивающихся странах. 